\title{
The Virgin's Consent
}

British Muslim Identity, Cultural Heritage and Gender in Young Adult Fiction

\author{
Claire Chambers and Indrani Karmakar
}

\section{Introduction}

In this chapter we examine postsecular Young Adult (YA) fiction focusing on young women protagonists, written by three authors with South Asian Muslim heritage. This heritage is not only where our joint expertise intersects but also where some of the most divisive and urgent faultlines in multicultural Britain today can be found. Such faultlines, as we will see, include issues relating to gender and sexual choices, as well as to the complex dynamics of religious and cultural affiliation. We have selected two short stories and two novels from the woefully small amount of YA writing published by Muslim-heritage authors in Britain. The two stories-Sufiya Ahmed's “Tears and Tantrums" and Nazneen Ahmed's "Ghazal" - are published in the new anthology A Match Made in Heaven, which Claire Chambers co-edited with Nafhesa Ali and Richard Phillips for publication by the multicultural London publisher specialising in YA, HopeRoad, in 202O. Meanwhile, the novels-Sufiya Ahmed's Secrets of the Henna Girl (2012) and Muhammad Khan's I Am Thunder (2018) - are $2010 \mathrm{~s}$ works of YA fiction dealing with a generational clash between British Muslim teenagers and their parents or other elders. The four texts deploy first-person narrators or extensive focalisation from the perspective of young characters, all of whom are gendered as female, thus providing formal as well as contextual suture.

Our chosen texts, we will suggest, zoom in on headstrong young women (most, though not all of them, adolescents) from South Asian Muslim backgrounds as a way of exploring a renewed sense of religious identification among young Muslims. Women and girls are of paramount importance in the featured texts. They all feature a fugue of Muslim women's (and, to a lesser extent, men's) voices, and most of them problematise the gender variable in one way or another. Similarly, the texts explore religion (and, in particular, Muslimness) and culture (Pakistani, Bangladeshi and more broadly South Asian) as identity strands that are closely intertwined and yet are often interpreted as irrevocably opposed or clashing with each other. Nazneen Ahmed's story and Muhammad 
Khan's novel petition readers to consider that the religion-culture binary is problematic. The categories of religion and culture not only stand in close proximity to each other, with their boundaries blurred, but also often merge together to make a distinct third category. However, all three writers demonstrate that such interconnectedness between religion and culture does not necessarily mean that the two issues are indivisible. Whereas Sufiya Ahmed privileges Muslimness from a gendered perspective and Nazneen Ahmed has less to say about Islam and more about Bangladeshi (and, to a lesser extent, Pakistani) culture, our essay will demonstrate that the final writer Muhammad Khan finds some kind of equilibrium between religion and culture.

The reconfigured faith-based affiliations that have been resurgent among British Asian Muslims in recent years need to contend with longstanding cultural identity components which stem from the Indian subcontinent-for the purposes of this chapter, specifically from Pakistan and Bangladesh. As Chambers and others have argued elsewhere (Phillips, Chambers, Ali, Hopkins and Pande 2019), some second-generation young British Muslims tend to extol their religious identity over and above their parents' ethnic affiliations. The rise of the category "Muslim" and the organisation of Muslims around this category is a process which can be traced back to the 1980s (with the Honeyford controversy of 1984 and, more prominently, the Rushdie affair from 1989 onwards). The designation and its mobilisation have of course acquired new valences in our post-9/11 period (Ranasinha 2007; Fisher, Lahiri and Thandi 2007; Chambers 2019). In this present context, many young people have been alienated by their strong sense that the majority culture does not understand them. They themselves may conversely find that same mainstream worldview hard to comprehend. Because of this, an easily fathomable response and mode of self-actualisation is to hold on to a stronger and more static notion of identity - especially as they justifiably view this Asian Muslim identity as coming under attack.

A similar phenomenon of new forms of religious identification being chosen by young Muslims, yet related to the African diaspora in this instance, is dramatised in a well-known scene from Leila Aboulela's novel Minaret (2005). In this work of adult literary fiction, the protagonist Najwa asks her love interest, Tamer, whether he feels Sudanese. He responds with an account of his transnational family's globetrotting lifestyle and concludes that "being a Muslim" is his identity. Najwa is similarly ambivalent about her Sudanese nationality, in her case because of involuntary exile in the London diaspora rather than affluent cosmopolitanism. She tells Tamer: "Like you, I just think of myself as a Muslim" (Aboulela 2005, 110). Such declarations may be located within a broader history of racism, in which minorities identify themselves and are viewed by 
others less through the lenses of skin colour, ethnic group and nationality, and more in relation to culture and religion, especially those practices associated with Islam (Modood 2005, 3-7). It should not escape our attention that such a religious preoccupation is additionally coloured by and should be read within the context of Western anti-Muslim sentiment, particularly after 9/11.

We might also situate such developments within a twenty-first century postsecular context (Habermas 2008), where religion, far from withering away, has experienced a revival in public debate. Researchers have found that many young people - women in particular-are distancing themselves from cultural traditions and family expectations (Hamid 2011; Rozario 2012; Mohammad 2015). As Philip Lewis and Sadek Hamid note, these young Muslims seek "to disaggregate Islam from religious and cultural norms deemed dysfunctional in Britain" (2018, viii). Some resist their elders' assumption that they will take spouses from the home country (Charsley 2005a, 2005b; Charsley and Bolognani 2016). Others, more positively, develop agency to select attractive features that they associate variously with Britain, specific parts of South Asia and the religion of Islam.

As part of this renascence, faith-based forms of identification are displacing ethnicity, nationality and other elements of subjectivity (Bailey and Redden 2010; Ratti 2013). Writing about the shifting nature of people's ideas of "belonging", Nira Yuval-Davis argues that as "the emotional components of people's constructions of themselves and their identities become more central the more threatened and less secure they become" $(2011,15)$. Yuval-Davis's incisive remark can help us understand the efforts of many younger-generation Muslims to cling to their beliefs and pious praxis as identificatory moorings. These efforts are becoming increasingly desperate in the often hostile and politically polarised environment of this second decade of the twenty-first century. An upsurge in religiosity frequently co-exists symbiotically with a concomitant growth of ambivalence towards their elders' customs, beliefs and practices - a cultural heritage which is seen by the young protagonists for much of their narrative journeys as remote and irrelevant.

Yet as Kamila Shamsie told Chambers in an interview: "The Islam I grew up among didn't make distinctions between the sacred and secular, and intermingling of traditions makes it hard to separate religion from culture" (qtd. in Chambers 2011, 225). Situating this intermingling of traditions in an academic landscape, Robert Gleave questions the validity of any hierarchisation as regards interpretations of Islam as a culture and as a religion. He argues that if we classify Islam solely as a religion, we risk buying into the Salafi argument that positions religion as blameless and culture as a damaging appendage that has attached to it. On the other hand, Gleave criticises social scientists and 
area studies experts who are riveted by the civilisation, ideas and actions of Muslims, but not the broader doctrines and belief systems adhering to Islam. A better approach, he suggests, is to problematise a binary understanding of the apparently separate categories of religion and culture, moving instead towards an exploration of their commonalities. As Gleave attests, scholars need to move "from an uncritical acceptance of the category of 'religion', towards a critical interrogation of 'religion' as a category" (2010, n.p.). Timothy Fitzgerald $(2009,6)$ has accordingly gone as far as to argue that this category of religion is a relatively recent invention, designed by secular modernity as an Other against which it can define and identify itself.

Identity is in turn a malleable entity that is constantly in the process of change and transformation. As Stuart Hall puts it so eloquently, "Perhaps instead of thinking of identity as an already accomplished fact, which the new cultural practices then represent, we should think, instead, of identity as a 'production', which is never complete, always in process, and always constituted within, not outside, representation" (1990, 222). In addition to this idea of identity as a production or performance (see also Butler 1988), a person's religious affiliations as a Muslim orbit and collide with other signifiers—such as gender, social class, age and national origins - which assume various degrees of importance in different situations. Here we draw on Kimberlé Crenshaw's (1989) highly influential work on intersectionality. Intersectionality is a theoretical approach that allows for simultaneous recognition of multiple identity integrants and grounds for oppression. As well as race and gender are class, religious background, age, disability, sexual orientation and so on. It is therefore crucial not to see the woman as an ahistoric, uncategorised, monolithic subject (Mohanty 1984). Rather, it is necessary to consider women in all their multiplicity and within their particular contexts. Therefore, when we analyse the primary texts, it will be necessary to engage with the potential intersections between different identity signifiers throughout, even while the gender aspect remains especially prominent in all the texts.

Fictional representations of British Muslim youths encourage an examination of the constituents of religious identity. Such an approach is especially pertinent because of the already-identified tendency of Muslims to affiliate closely with their religious group in recent years. Young people in particular are increasingly keen to portray themselves as Muslims, rather than by their parents' or grandparents' nationalities (Lewis 1994, 176-89; Mondal 2008, 3-6). Anshuman Mondal describes this as a "trajectory away from a 'western' lifestyle to one more focussed on Islam" (2008, 8). Meanwhile, Philip Lewis writes of young people forging "an exploratory identity, which, unlike the majority of parents, sought to interpret Islam as relevant to their lives outside home and 
ethno-religious enclave" $(2008,8)$. In using the term Muslim these young people tend not to be thinking seriously about Islam's tenets or religious practices. Instead, many see the word Muslim as a springboard launching them into a constellation of global (even post-ethnic) Muslims in the Ummah, or worldwide Islamic community. Embracing Muslimness also distinguishes them from both mainstream society and their parents' perceived folk beliefs or alleged misunderstandings of Islam's "true" teachings. While Islam is part of their families' background and their parents do not profess any other faith, the older generation are often associated in their children's minds with cultural accretions and possibly the Hinduisation of the religion. As such, some of the young women protagonists rebel against both male elders and what Lize-Maree Steenkamp (2019) terms "patriarchal women". The former vocally lay claim to the upper hand in debates with their elders that deal in moral or spiritual deliberations. It is such intersectional speech-acts and claims by young Muslim women that we wish to explore through the readings that ensue. These YA authors are intervening in established representations of British Muslims, complicating widespread assumptions about the passivity and compliance of the young Muslim woman in the face of perceived Islamic strictures.

\section{Sufiya Ahmed, Secrets of the Henna Girl and "Tears and Tantrums"}

Sufiya Ahmed published her award-winning Secrets of the Henna Girl with Puffin Books in 2012. Its epigraph is the hadith "Obtain the virgin's consent before you marry her" (Ahmed 2012, vii). The YA novel centres on a 16-year-old girl, Zeba Khan, who is being forced by her parents into marriage with a cousin in their home country. Forced marriage is a form of nuptials involving coercion and a complete lack of consent from one or both the parties. This cruel and unusual practice affects a number of communities within Britain, including British Muslims (Asli and Amrollahi Byouki 2016; Gill and Hamed 2016). Concern about forced marriage remains a controversial issue since it is often framed within Orientalist narratives. Much mainstream Western media coverage uses such narratives either to reinforce the superiority of so-called liberal values; or to leverage Muslim male violence as "empirical evidence" of Muslims infesting the West, bolstered by multicultural policies (Patton 2018,21 ). While it is true that sometimes Islamic law is used to justify forced marriage, many scholars have shown that the practice is incompatible with Islamic jurisprudence for it violates the basic tenets of Islamic laws on choice, consent and guardianship (Halim 2010; Gill and Hamed 2016). Intersectional feminists have argued that the popular Western discourse concerning forced 
marriage normalises racial stereotypes of oppressed Muslim women in dire need of rescue (Razack 2004, 130). Writing about the overwhelmingly racialised presentation of forced marriage in media coverage in the United Kingdom and Australia, Chloe Patton observes that this "domestic violence [...], while shaped by culture, is not reducible to it" $(2018,23)$. She justifies this point by arguing that forced marriage cannot be seen as a straightforwardly "cultural" practice, given the huge variations in customs and conventions between the countries where instances of forced marriage are high. Put differently, other factors than culture come into play, which include economic development and stark social divisions.

Ahmed decided to write Secrets of the Henna Girl when she was working as a parliamentary researcher for a New Labour MP in the 200os. It was through her work in parliament that she met a group of Asian women activists who were campaigning to raise awareness of the issue of forced marriage as an ongoing problem in these communities. Some of the activists were also lobbying to make coercive unions illegal in the United Kingdom. The legislation to categorise forced marriages as illegal was subsequently passed in 2014 (Erlanger 2014, n.p.). Ahmed's novel, set in both Yorkshire and Pakistan, is a story of girls' rights and empowerment. In it, the author makes a clear distinction between arranged and forced marriage, showing that unlike an arranged marriage, a forced marriage will never yield a successful union. Given arguments about Western "saving discourse" (Abu-Lughod 2002, 788-89; Cilano 2015, 157), it is conspicuous that Ahmed tries to write about these issues with sensitivity. As we will show, she is not so simplistic in her fiction as to blame female oppression on Islam, as many Western commentators do (Khan Phillips 2012). In sidestepping this set of stereotypes, she falls into the different trap of allocating the culpability for forced marriage to Pakistan as a country. In the final analysis, this nation and its cultural values come across problematically as a threat to the British-born protagonist.

From the novel's earliest pages, Pakistan and its culture are freighted with mostly negative associations. For instance, Zeba, the first-person narrator, recalls her first and only visit to the country (at the age of eight) as a place bustling with overbearing relatives and servants. She declares dismissively: "I did not have good memories; it had been hot, full of mosquitoes and little else" $(2012,2)$. She is now contemplating her imminent second visit with trepidation, since when they are there her father always behaves differently in front of his patriarchal older brother. He acts as though having a daughter is burdensome, and Zeba finds herself judged as to the lightness (or otherwise) of her complexion and the consequent extent of her eligibility for marriage. However, once she arrives in Pakistan on this particular trip, Zeba is struck by her warm 
welcome (as well as the poverty and the omnipresence of guns). She begins to make some more fine-grained distinctions between the area she is visiting, Karachi and rural Sindh, and other regions in Pakistan.

Yet in the final analysis, Ahmed draws an asymmetrical distinction between religion and "cultural thing[s]" (2012, 28), with our sympathies directed towards the former. She does this by making Zeba account for her preference for Islam over cultural traditions as part of a spirited response to her coerced engagement to a cousin, Asif. Like several of the British Muslim interviewees from the sociological literature cited in this article so far, her protagonist is at pains to emphasise that she "wasn't Pakistani [...], not in the real sense" (2012, 28). Instead, she stresses her British birth and values, as well as her allegiance to Islam rather than to cultural traditions. Her wise grandmother Nannyma tells her, "The Qur'an protects women. I suggest you read it properly" (2012, 79). In a sense, the rest of the novel concerns just such a gendered religious education. In this Bildungsroman aimed at a teenage audience, Islam becomes a powerful resource as Zeba resists the forced marriage designed without her happiness in mind so as to strengthen family ties. She learns that "a girl's consent is required for a marriage to be valid" $(2012,137)$, that forced nuptials are "against our religion" $(2012,138)$ and that "God does not permit the subjugation of women" $(2012,139)$. The local mosque's male imam, alongside her spiritually-minded grandmother, are two rare examples of sympathetic Pakistani characters who protest against Zeba's non-consensual engagement and try to stop the wedding. Imbibing their teachings, Zeba is an example of an adolescent character who comes to identify herself as a Muslim and thus transcend national, familial and ethnic demarcations. At the end of the novel, she impugns forced marriage as follows: "And that is what the practices are: tradition, not religion" $(2012,246)$. While Ahmed takes an important step in recuperating Islam from commonplace charges that it is inimical to women, she elevates the religion only to denigrate Pakistani traditions and culture.

Ahmed's short story for the above-mentioned anthology A Match Made in Heaven, entitled "Tears and Tantrums", continues the author's interest in gender and religion. It addresses the cultural appropriation and narrow interpretations of Islamic ideas which are often used to subjugate women within patriarchal structures. As such, the narrative enacts a confrontation between conventional interpretations of Islam's stance on gender on the one hand, and a radical departure from this on the other. In doing so, the story sketches what a revision of Islamic faith from a female perspective might look like. It demonstrates that Muslim women are revisiting, adapting and rewriting what being Muslim and female means. In this story, as in Ahmed's novel, the relationship 
between religion and gender is a close one and the two identity parameters frequently intersect in both texts.

The story's first-person narrator-protagonist is Fatima, a young woman in her mid-twenties. Three years into their marriage, Fatima's husband declares his wish to marry another woman while keeping her as a co-wife. At first devastated by this revelation, Fatima ultimately decides to walk out of their marital home, inspired and encouraged by her Islamic faith. The author's aesthetic choices are intimately connected to the politics of the text. As such, the story has a tripartite structure, with three tranches of text focusing on the issues of dishonour, Sunnah and Talaq (divorce) respectively, referring to cultural and Islamic-adjacent concepts. Women are unfortunately seen as the seat of (dis)honour in many cultures and not only South Asian Islam (Meetoo and Mirza 2007, 187-88). However, in the Sunnah (the example of the Prophet Mohammed's own words and deeds), both men and women were held accountable for their actions, and strong women venerated. Accordingly, in the middle section of the story, Ahmed reminds her readers that Mohammed's first wife Khadija was a wealthy businesswoman who was 15 years older than him, and that "[t]heirs was a marriage filled with love and respect" $(2020,57)$. Under Sharia law, a threefold pronouncement of the word "Talaq" by a man to his wife can result in divorce. However, as Nehaluddin Ahmad observes, there is substantial mitigation, as these utterances "have to be spaced over a period of 3 months to give husband and wife time for reconciliation" (2009, 53). Thus, while a snap divorce is not unheard of within the religion, it is hedged around with so many conditions as to make Islamic feminists convinced that it is impossible to carry out by any Muslim with a clear conscience.

Such religio-cultural diktats and their deleterious effects on women invite the popular Western idea of Islam as inherently oppressive towards women, a tendency that has received substantial criticism from Islamic feminists. Leila Ahmed, in her seminal work Women and Gender in Islam, has argued that the issue of gender and especially "the peculiar practices of Islam with respect to women" have long been hijacked to fit "the Western narrative of the quintessential otherness and inferiority of Islam" (1992, 151). In her "feminist interpretation of women's rights in Islam", Moroccan sociologist Fatima Mernissi accordingly unravels the discrepancy between the Prophet's egalitarian message and the patriarchal scaffolding erected around this by the male elite. She contends that the sacred texts have not only been "manipulated" but also that the very process of manipulation is "structural[ly] characteristic of the practice of power in Muslim societies" (1991, 8). Both of these scholars argue against homogenising interpretations of Islam, since "no single or unique meaning of, and approach to, gender issues can be identified in early Islam, not even 
during the Prophet's lifetime" (Calderini 2008, 625). Through their searching works on early Islamic texts, they demonstrate the democratic messages of the Prophet. However, subsequently the "institution" begins to dominate the religion, replacing "egalitarian and 'democratic' " Islam with “ '[...] establishment' Islam” (Jackson 2018, 62). The ideological premise behind Ahmed's story partakes in Mernissi's and Leila Ahmed's Islamic feminist impetus to recover Islam from the patriarchal establishment and hegemonic colonial narratives. Sufiya Ahmed might not explicitly define herself as an Islamic feminist. Yet her project of revisiting and revising Islam from a gendered perspective communes with and brings to mind much Islamic feminism.

At the story's outset, we encounter Fatima as a weak and vulnerable character, who is preoccupied with maintaining her svelte figure and smart grooming so as not to lose her husband's interest. When a distressed Fatima runs to her mother with the shocking news of her husband's expedient new commitment to polygamy, the elderly woman, a much-respected member of her community and an "immaculate housekeeper", blames her daughter thus: "What have you done to push him away? [...] Don't you sleep with him? You have to meet their bodily needs or their eyes wander" (Ahmed 2020, 53). This bespeaks a demeaning notion of the marital relationship based on unequal power dynamics, in which it is the wife's duty to keep her husband sexually satisfied. Furthermore, a patriarchal idea of honour, the onus of which is always on woman, is evident in her mother's ensuing order: "You will not do anything to dishonour the family. You won't leave him. There will be no divorce" (2020, 54). Her mother advocates for obedience and patience, those virtues culturally associated with women. Indeed, the figure of the matriarch plays a central part in the system of negotiation, accommodation and collaboration that Deniz Kandiyoti (1988) calls "bargaining with patriarchy". The mother tries to make her daughter complicit with her own subjugation as a woman. This maternal character's acquiescence with conventional mores is indicative of internalised patriarchal notions of shame and honour. In its first part, the story presents these dominant but regressive gender norms through the mother, only to challenge them in the two parts that follow with the decisive acts of the daughter.

As the heartbroken Fatima tries to hold herself together amid turmoil, the peaceful serenity of the mosque gives her the necessary solitary space for introspection. Significantly, unlike her mother who is keen for Fatima to avoid "dishonour" by continuing in the marriage, the mosque's alimah (a female scholar of the Qur'an, see Ismah 2016; Farida and Kasdi 2018) provides her with moral support. The alimah reminds Fatima that Islam buttresses women's right to leave their marriages if they are unhappy. Empowered by the alimah's assurance that a divorce is in accordance with the Sunnah, Fatima elects to separate 
from her husband. It is by no means a coincidence that Fatima's confidante and aide is an alimah. The interaction between the alimah and Fatima, and the latter's subsequent decision to brave social stigma as well as financial hardship in leaving her husband, invites a revision of religion in feminist terms. Indeed, readers are encouraged to interpret the relationship between these women as an example of "female solidarity" (with all the connotations this phrase might entail) forged via religion. Female solidarity is a live issue that has long been contested within feminist circles. Solidarity among women across culture and religion has been valued, even mythologised, in single-issue feminist movements. However, the universal category of woman and the notion of shared oppression as a site for unity have received strong criticism from such intersectional feminists as bell hooks and Nira Yuval-Davis. In her work, hooks prioritises political commitment rather than similarity as the foundation of solidarity among women $(1986,125)$. Correspondingly, Yuval-Davies advocates for a solidarity built not on shared victimhood but on emancipatory ideas held in common. This story exhorts a similar idea of female solidarity predicated on liberatory ideals. More importantly, it limns religion as the potential fulcrum for such female solidarity; and culture is depicted as the sisterhood's downfall—especially where sexual relationships are concerned.

Sexual relationship attitudes and practices, as the sociological findings cited earlier claim, constitute one of the areas where a negativity towards Pakistani or Bangladeshi heritage is most apparent. We can surmise that Sufiya Ahmed's narrative arc in several ways echoes and validates such findings. More importantly, Ahmed's story provides an alternative window onto the challenging of the established doxa about Islam. Some of these received ideas may be rooted in distorted versions of Islam or interpretations of Islam moulded by patriarchal beliefs or Islamophobia. Other outsiders portray Muslims as less free, even less happy than others (Shaw 20o6), particularly in their personal and sexual relationships (Chambers, Phillips, Ali, Hopkins and Pande 2019).

While the text effectively reveals the distinction between cultural and Islamic values-and even suggests a revision of some aspects of the latter, as is evident in the alimah's condemnation of polygamy - it can seem rather didactic at the expense of literary nuance. "Tears and Tantrums", like its novelistic forebear Secrets of the Henna Girl, functions as an invitation to "recover" Islam from its distortions. This explains the existing tensions in the narrative between traditional conceptualisations of the Islamic faith (as represented by the protagonist's mother) and a more radical approach to Islam (as represented by the alimah). The narrative foregrounds gender identity within the context of Islam by fictionalising these identity constituents' tensile present. In Ahmed's women-centred fiction, the espousal of Islam as a possible way out 
of contemporary conflicts entails a wholesale and gendered reconceptualisation of the Muslim faith, which has been usurped by male figures of authority to exclude women from public life. In the process, though, culture is stereotyped as backward and oppressive.

\section{Nazneen Ahmed, "Ghazal"}

Worries about parental expectations, especially in terms of career choice, figure strongly in Nazneen Ahmed's short story "Ghazal". The story is more concerned with customs and lifestyles than religious identity. Muslimness is evoked rarely, being understood more as a cultural identity than one involving belief and orthopraxy. "Ghazal" revolves around Ahmed's Bangladeshi-heritage protagonist Rokeya, who is about to return home after almost a decade away, during which period she completed a medical degree and started her career as a family doctor. The narrative soon moves back in time as Rokeya, having opened an old keepsake box, reminisces about an evening nine years ago when she was still a teenager.

Told through free indirect discourse aligned with Rokeya, from its inception the story underlines the generation gap through the girl's uneasiness with her father's allegedly typical behaviour as an overbearing Asian parent. Indeed, we witness the older generations' attempt to hold onto their culture, whether through the conspicuous display of respect owed to a local "chieftain" (N. Ahmed 2020, 14) which Rokeya's father expects from the other members of the community, or his disapproval of Rokeya's choice to wear casual clothes to a social gathering of ghazals and music. We see other forms of cultural demand exerting themselves, as Rokeya is careful not to smile at her childhood friend from a Pakistani background, Iqbal, and thus invite the inquisitive glances of older people or "uncles" present at the programme. This shadows forth a subtle tension between the two generations, adhering to often-conflicting cultural views between younger and older people.

It is worth noting that Ahmed's young British Bangladeshi protagonist is not entirely indifferent towards her cultural heritage, and nor does she harbour complete antipathy or apathy for the subcontinent. This is especially evident when it comes to her avid interest in ghazal poetry, despite the fact that she does not understand Urdu. In this form of verse, sound, rhythm and music come to the fore, explaining Rokeya's penchant for couplets the meaning of which she cannot really grasp. Ahmed also uses the olfactory to describe the atmosphere of the small suburban town inhabited by many migrants. She writes of the smell of "biryani [which] mingled with floor polish and the disinfectant 
she remembered from primary school" (2020, 14). This chokingly incongruous depiction from Rokeya's standpoint of the rich spices of South Asian cuisine mixing with the antiseptic air of cleaning products adds an extra layer to the narrative, underlining as it does the second-generation immigrant's uneasy confluence of cultural identities.

The crux of the story, though, lies in the aspirational clash between the two generations. There are no melodramatic instances of abuse or violence in "Ghazal". Instead, what readers initially perceive is an understated sense of anxiety regarding British Muslim youth and their cultural demands. Simmering tensions soon bubble up in the first conversation between Rokeya and Iqbal after they encounter each other in adulthood. Iqbal congratulates Rokeya with heavy irony when he learns of the imminent start of her мввs degree: "The Asian Dream. Your Abba's so proud" (2020, 20). Iqbal's words indicate the demands exerted on these young people by their elders. Despite his swipe at her apparently conformist leanings, Rokeya strikingly reveals a purely pragmatic ambition behind her degree choice: "Med school was the only way I'd ever have been able to live away" $(2020,22)$. She had wanted to pursue her love of art and become a painter, but the desire to live an independent existence was too urgent to ignore. On returning home, the following quotation captures her claustrophobia: "She began to have that feeling again, of walls closing in, of her lungs compressing. Expectations, assumptions, duty: her fluid, free self being squashed down into a respectable box. She walked faster, as if by doing so she could outrun it" $(2020,20)$. These intense lines illustrate the extent to which cultural expectations impinge on young individuals and their choices. As the two young teenagers reflect on their compliance and conformity, Iqbal says self-deprecatingly: "Look at us. The good, obedient, miserable Muslim kids" $(2020,22)$. Here, being Muslim and its associated duties are perceived from a cultural point of view rather than a strictly religious or faith-based perspective.

Notwithstanding their children's understandable grievances, the older generation of migrants are not presented as monochromatically villainous. Readers see the protagonist talking about the older generation and their struggle in a sympathetic light, and drawing on earlier experiences for her generation's future endeavours. Rokeya tries to inspire Iqbal to follow his childhood fantasies by cajoling him to go travelling:

Come on, Iqbal. It'd be an adventure. Your dad—my dad—-they had theirs, when they came here. Untied, unmarried, who knows what they got up to. You deserve adventures too. You deserve some happiness-just a bit. Then you can come back, get married to a nice Pakistani girl, and you'll have it to look back on. The time you were happy. $(2020,23)$ 
From this it can be discerned that "adventure[s]" and "happiness" are more for the taking of men, since the dream is held out to Iqbal—with his father and Rokeya's own as the role models. The anecdote's only female exemplar, the "nice Pakistani girl", is imagined as someone to settle down with, being excluded from any intrepid or fun escapades. Crucially, though, the story is not recounted as a tragic tale of women's oppression or the young adults' sacrifice at the altar of parental expectation. At the end of the story, we see Rokeya not as a bitter person who has abandoned all her earlier artistic hopes. Rather, she is someone who has come to love general practice for the creativity it affords, even though the medical profession was initially regarded only as a respectable way escape route from home. What emerges from the teenager's complex relationship with home and its attendant concerns, namely parents' expectations - which are largely culturally constructed-is a profound sense of the ambivalence of young British Muslims towards their cultural heritage.

Nazneen Ahmed has selected an apt title, as the story is a mixture of romantic and melancholic elements, just as are stitched into the ghazal poetic fabric (Chew 1996; Mufti 2004). Many ghazals revolve around the theme of lovers' separation. This topic often functions as a figuration of the Muslim worshipper's longing for Allah (Mufti 2004, 259) or, in relation to Ahmed's long-separated lovers Rokeya and Iqbal, as touching upon a second-generation migrant's yearning for home and belonging. Amid these allusions, her main characters' names are also well-chosen. For if the speculative story "Sultana's Dream" (Hossain 1988/1905) by Bengali woman writer Rokeya Sakhawat Hossain (1880-1932) was one of the earliest works of Muslim fiction (Malak 2005, 3), that text's utopian imagining of a matriarchal world chimes with Ahmed's character's feminism. A contemporary writer to Hossain, the poet Mohammad ("Allama") Iqbal (1877-1938), helped to conceptualise Pakistan but did not live long enough to see the country's creation. During the course of his illustrious poetic career, Iqbal wrote dozens of ghazals. Some of these poems have been set to music and sung by well-known South Asian musicians including the late Mehdi Hassan and Nusrat Fateh Ali Khan as well as the female singers Lata Mangeshkar and Sanam Marvi. In this way, Ahmed weaves intertextual references into a "hybrid tapestry" (Shamsie 2017) in portraying her teenage Bangladeshi and Pakistani characters' ambitions and desires.

Another YA novel with much to say about the intricacy and uncertainty of relationships between British Pakistani youths, the subcontinent and Islam 
is Muhammad Khan's I Am Thunder (2018). Khan teaches mathematics at a high school in south London, and his pupils' influence on him is evident in one of the novel's most successful aspects: its deft rendering of the rhythms and argot of Multicultural London English (see Cheshire, Kerswill, Fox and Torgersen 2011). Linguistically hybrid slang words such as "peng", "bruh" and "mandem" are liberally scattered through his pages, making Khan's adoption of the teenage British Muslim voice especially convincing. I Am Thunder pivots on the religiously serious but culturally transgressive young protagonist Muzna Saleem who is prepared to disappoint and confront family members when the need arises, and to defy cultural conventions.

Pakistan is associated with strict parenting and a close-knit community in the novel. During one conversation with her best friend about whether or not to look for a relationship with a boy, the friend says about Muzna's parents: "[A]ll they care about is you not embarrassing them in front of the bitchy-arse Pakistani community. Meanwhile you're so damaged, you think dating is perverted" (Khan 2018, 39). This indicates the prominent role of cultural norms in shaping parents' expectations, as well as the fear of community tittle-tattle that often prompts parents to impose various rules and precepts on their children.

Indeed, Muzna's parents make her change high schools once her rebellious best friend Salma is found in bed with a boy. They are worried that Salma's tarnished reputation may damage by proxy the standing of their own daughter. Given these pressures, girls' insubordination can take the form of putting faith above family and the culture that is identified with Pakistan. In other words, a turn to religiosity offers a route to rebellion that is hard for community members to argue with. Accordingly, Muzna becomes involved with a religious group (initially she does not realise that they are extremists) as a way of resisting her parents but managing to remain within relatively acceptable bounds. Early in the novel she expresses contemptuous thoughts about her parents to one of these religious hardliners. In an effort to groom her via a shared empathy for their similar circumstances, a male interlocutor writes online, "My parents weren't proper Muslims. Like all the stuff you learn in RS about Islam was the stuff we never did. Pakistani Culture was their god". Agreeing with this scathing assessment, Muzna thinks: "According to the Gospel of Dad, being a 'good Pakistani' was everything and being a 'good Muslim' came second. I could belt out Noor Jehan's top five hits in Punjabi, but don't ask me to recite five surahs from the Qur'an" (Khan 2018, 22). Muzna's father is dismissive of girls in Britain who wear hijab. He is a barely practising Muslim, who has given his daughter little to no religious education but instilled in her a deep reverence for Pakistan's best-known female singer Noor Jehan. 
The fact that both the father and mother's values are cultural is underscored by the comparable behaviour and beliefs of the parents of Sarabi, a new friend Muzna takes after she is banned from seeing Salma. Sarabi, like Muzna, traces her heritage to the Punjab, but to the eastern, Indian side. Yet Sarabi's parents are just as strict with their daughter as Muzna's Punjabi Pakistani parents. Whether Sikh like Sarabi, Muslim like Muzna (or implicitly also Hindu Punjabi), it appears that stifling, honour-based norms around a girl child's chastity and presentation to the world are hard to avoid.

Muzna's parents' deified "Pakistani Culture" is shown to incorporate into its fold children's relationship choices and arranged or even coerced marriages. By contrast, Muzna wants to choose her own, religiously-educated partner. When her mother upbraids her for starting to wear the hijab, Munza emphatically asserts her personal choice when it comes to her faith. Replying to her mother, she reflects further: "Arif may have got me into it, but wearing my hijab was between me and God and nobody else" $(2018,186)$. She is astute enough to consider her parents' prohibitions against the headscarf as similarly extremist to those rules prescribing full coverage for women. Trying to occupy an ethical high ground, young people like Muzna challenge distorted versions of Islam or even interpretations of Islam moulded by patriarchal beliefs (as also happens in Judaism and Christianity)—hence the need to separate Islam from patriarchy.

What is more, though, I Am Thunder shows that Islam continues to be distorted, even if in different ways, by new generations. It is through her interactions with Arif, a very good-looking British Pakistani boy originally from Manchester, that she becomes lured into the extremist group. However, the fact that Arif takes an interest in overweight, hirsute Muzna has little to do with her personality or, later, her newfound piety (as she naively assumes). Having been sexually abused by an uncle as a young boy, Arif is easily manipulated by his sinister elder brother Jameel. It is the latter who has instructed the young Adonis to court Muzna, and in the process recruit her to ISIs. Too kind-hearted to groom her in the cynical way Jameel stipulates, Arif's connection with Muzna develops into a real, albeit fragile, relationship.

At the point in the text when Muzna becomes involved with Arif, even entering into a rushed and furtive marriage with him at the tender age of 16 , the binary set up early on in the novel between apparently oppressive Pakistani culture and liberatory Islam begins to break apart into something more gradated. At her moment of crisis, as she gradually becomes aware of Jameel's allegiance to ISIS, Muzna thinks of her parents' culture as a resource and even a tool of resistance. She gains strength from recalling her father telling her she is a "Pakistani lioness" (2018, 99). Later, when Muzna is trapped with Arif in 
a house that Jameel has torched rather than see the young couple leave his Islamist group, Arif uses a cricket bat embossed with an image of the Pakistani flag to smash the window, enabling their escape. Pakistan thus symbolically saves them, the cricket bat emblazoned with the Islamic Republic's crescent moon and star betokening an inchoate and contingent nationalism. As a sport, cricket is a source of national pride within the contest of postcolonial relations and the global capitalist system (Westall 2016). For much of the novel until this point Muzna would have passed Norman Tebbit's pernicious cricket test, which the Conservative MP proposed in 1990 as a method to determine Englishness based on what team individuals supported (Crabbe and Wagg 2005, 205). She was uninterested in and had little affinity to Pakistan, regarding herself as British through and through — albeit a Briton with an exponentially increasing fervour for her Muslim faith. Now she accords greater respect to Pakistan's secular and folk culture. Even though the most visible saviour in Arif's and Muzna's rescue is a white man (with the telling name of Officer Redman) from the counter-terror police, culture in the form of Pakistani symbols and sports gives the young couple the courage to save themselves. In sum, then, IAm Thunder does not shy away from criticism of extremist distortions of religion or draconian parental twisting of culture. Simultaneously, though, this YA novel also lambasts racism and shows how both Islam and Pakistani culture can sustain young people going through identity and other crises.

Given the lack of cultural diversity in British YA fiction (Flood 2014, n.p.), it is a positive development that these diverse authors of South Asian Muslim heritage are getting published and winning recognition and plaudits. More importantly, these authors are creating strong young women protagonists who not only bust popular stereotypes of hapless victims but also manoeuvre the exigencies of their multiple identities - gender, cultural and religious - in order to make their lifestyle and relationship choices. All the texts discussed here bring to the fore gender identity within the context of British Muslim culture by fictionalising their texture and frictions.

These texts raise urgent issues, which mostly relate to the position of British Asian women within their communities and, more generally, within Islam. The chosen authors unpick a triangulated relationship between "Muslim identity", South Asian culture and gender. Our chosen authors offer layered depictions of South Asian Muslim culture, in which culture and religion often intersect in in such a way that it becomes difficult to separate them from each other. As 
the narratives suggest, this conjoining of culture and religion has a profound impact on women. However, it is also possible to divide the authors into distinct constituents. For example, as our discussion demonstrates, Sufiya Ahmed has strong feminist reservations about those South Asian cultural accretions (such as forced marriage and unilateral, male-driven divorce) of which she thinks Islam should be cleansed. In the final two texts under discussion, characters learn to select only those aspects of South Asian culture that appeal and deploy these as affirmative resources.

Although it features a male protagonist and is therefore not discussed in this article, this last idea is dramatised vividly in Muhammad Khan's most recent novel Kick the Moon (2019). His protagonist Ilyas, an aspiring comic-book artist, creates a superhero character called PakCore. The name, he explains, has the following etymology: "Pak from Pakistan and Core from hardCore. Put 'em together and you get something sounding like parkour. That's his method of getting from A to B and making it look wicked" $(2019,126)$. Ilyas cherry-picks the most dynamic aspects of British and Pakistani culture, "put[s] 'em together", and makes something new and enabling. Certainly of the three key writers examined here, Nazneen Ahmed and Muhammad Khan are respectively producing BangCore and PakCore fiction. At once British and South Asian, religiously- and secularly-inflected, their teenage protagonists in all their rich variety give hope for the future of YA fiction.

\section{Works Cited}

Aboulela, Leila. 2005. Minaret. London: Bloomsbury.

Abu-Lughod, Lila. 2002. "Do Muslim Women Really Need Saving? Anthropological Reflections on Cultural Relativism and Its Others." American Anthropologist 104 (3): 783-9o.

Ahmad, Nehaluddin. 2009. "A Critical Appraisal of 'Triple Divorce' in Islamic Law." International Journal of Law, Policy and the Family 23 (1): 53-61.

Ahmed, Leila. 1992. Women and Gender in Islam: Historical Roots of a Modern Debate. New Haven, CT: Yale University Press.

Ahmed, Nazneen. 2020 [forthcoming]. "Ghazal." In A Match Made in Heaven: British Muslim Women Write About Love and Desire, edited by Claire Chambers, Nafhesa Ali and Richard Phillips. London: HopeRoad.

Ahmed, Sufiya. 2012. Secrets of the Henna Girl. London: Puffin.

Ahmed, Sufiya. 2020 [forthcoming]. "Tears and Tantrums." In A Match Made in

Heaven: British Muslim Women Write About Love and Desire, edited by Claire Chambers, Nafhesa Ali and Richard Phillips. London: HopeRoad. 
Asli, Mehrdad Rayejian and Mojgan Amrollahi Byouki. 2016. "Forced Marriage in Islamic Countries: The Role of Violence in Family Relationships." In Women and Children as Victims and Offenders: Background, Prevention, Reintegration, edited by Helmut Kury, Sławomir Redo and Evelyn Shea, 729-53. Cham: Springer.

Bailey, Michael and Guy Redden. 2010. Mediating Faiths: Religion and Socio-Cultural Change in the Twenty-First Century. Farnham: Ashgate.

Butler, Judith. 1988. "Performative Acts and Gender Constitution: An Essay in Phenomenology and Feminist Theory." Theatre Journal 40 (4): 519-31.

Calderini, Simonetta. 2008. "Islam, Gender and Human Rights." In The Islamic World, edited by Andrew Rippin, 624-37. New York: Routledge.

Chambers, Claire. 2011. British Muslim Fictions: Interviews with Contemporary Novelists. Basingstoke: Palgrave Macmillan.

Chambers, Claire. 2019. Making Sense of Contemporary British Muslim Novels. London: Palgrave Macmillan.

Chambers, Claire, Richard Phillips, Nafhesa Ali, Peter Hopkins and Raksha Pande. 2019. “'Sexual Misery' or 'Happy British Muslims'? Contemporary Depictions of Muslim Sexuality.” Ethnicities 19 (1): 66-94. http://journals.sagepub.com/eprint/ nDF2pSMW6q37RRM9ytU4/full.

Chambers, Claire, Nafhesa Ali and Richard Phillips, eds. 2020 [forthcoming]. A Match Made in Heaven: British Muslim Women Write About Love and Desire. London: HopeRoad.

Charsley, Katharine. 2005a. "Unhappy Husbands: Masculinity and Migration in Transnational Pakistani Marriages." Journal of the Royal Anthropological Institute 11 (1): 85-105.

Charsley, Katharine. 2005b. "Vulnerable Brides and Transnational Ghar Damads." Indian Journal of Gender Studies 12 (2-3): 381-406.

Charsley, Katharine and Marta Bolognani. 2016. "Being a Freshie Is (Not) Cool: Stigma, Capital and Disgust in British Pakistani Stereotypes of New Subcontinental Migrants." Ethnic and Racial Studies 40 (1): 43-62.

Cheshire, Jenny, Paul Kerswill, Susan Fox and Eivind Torgersen. 2011. "The Emergence of Multicultural London English." Journal of Sociolinguistics 15 (2): 151-96.

Chew, Shirley. 1996. “A Question of Form: Phyllis Webb's Water and Light: Ghazals and Anti Ghazals." In The Contact and the Culmination: Essays in Honour of Hena Maes-Jelinek, edited by Marc Delrez and Bénédicte Ledent, 31-43. Liège: Liège Language and Literature.

Cilano, Cara. 2015. "Saving Pakistan from Brown Men: Benazir Bhutto as Pakistan's Last Best Hope for Democracy." In Imagining Muslims in South Asia and the Diaspora: Secularism, Religion, Representations, edited by Claire Chambers and Caroline Herbert, 157-71. Abingdon: Routledge. 
Crabbe, Tim and Stephen Wagg. 2005. "'A Carnival of Cricket?': The Cricket World Cup, 'Race' and the Politics of Carnival." In Cricket and National Identity in the Postcolonial Age, edited by Stephen Wagg, 204-22. Abingdon Routledge.

Crenshaw, Kimberlé. 1989. "Demarginalizing the Intersection of Race and Sex: A Black Feminist Critique of Antidiscrimination Doctrine, Feminist Theory and Antiracist Politics." University of Chicago Legal Forum 140: 139-67.

Erlanger, Steven. 2014. "Marriage by Force is Addressed in Britain." New York Times, June 16, 2014. https://www.nytimes.com/2014/o6/17/world/europe/ britain-forced-marriage-is-now-illegal-in-england-wales-new-law.html?_r=o.

Farida, Umma and Abdurrohman Kasdi. 2018. "The 2017 Kupi Congress and Indonesian Female 'Ulama.' ”Journal of Indonesian Islam 12 (2): 135-58.

Fisher, Michael H., Shompa Lahiri and Shinder Thandi. 2007. A South-Asian History of Britain: Four Centuries of Peoples from the Indian Sub-Continent. Oxford: Greenwood. Fitzgerald, Timothy. 2009. Discourse of Civility and Barbarity: A Critical History of Religion and Related Categories. Oxford: Oxford University Press.

Flood, Alison. 2014. "Diversity in Children's Books: Colouring in Required." Guardian, March 20, 2014. https://www.theguardian.com/books/2014/mar/2o/diversit y-children-books-colour-young-people.

Gill, Aisha K. and Taher Hamed. 2016. "Muslim Women and Forced Marriages in the UK." Journal of Muslim Minority Affairs 36 (4): 540-56o. DoI: 10.1080/ 13602004.2016.126o324.

Gleave, Robert. 2010. "Should We Teach Islam as a Religion or as a Civilisation?" "Islamic Studies Network: Perspectives on Islamic Studies in Higher Education" (Aston University, May 25-26), http://www.heacademy.ac.uk/assets/York/multimedia/audio/islamic_studies/Professor_Ron_Geaves.mp3 (URL no longer functional), unpublished paper.

Habermas, Jurgen. 2008. “Notes on a Post-secular Society." New Perspectives Quarterly 25:17-29.

Halim, Rubina. 2010. "Islamic Law Forbids Forced Marriage." Irish Law Times 28 (9): 144-46.

Hall, Stuart. 199o. "Cultural Identity and Diaspora." In Identity: Community, Culture, Difference, edited by Jonathan Rutherford, 222-37. London: Lawrence and Wishart. Hamid, Sadek. 2011. "British Muslim Young People: Facts, Features and Religious Trends." Religion, State and Society 39 (2-3): 247-61.

hooks, bell. 1986. "Sisterhood: Political Solidarity Between Women." Feminist Review 23: 125-38.

Hossain, Rokeya Sakhawat. 1988 [1905]. "Sultana's Dream." In Sultana's Dream and Selections From The Secluded Ones, edited and translated by Roushan Jahan, 7-18. New York, NY: Feminist Press. 
Ismah, Nor. 2016. "Destabilising Male Domination: Building Community-Based Authority among Indonesian Female Ulama." Asian Studies Review 40 (4): 491-509. Jackson, Elizabeth. 2018. Muslim Indian Women Writing in English: Class Privilege, Gender Disadvantage, Minority Status. New York: Peter Lang.

Kandiyoti, Deniz. 1988. "Bargaining with Patriarchy." Gender and Society 2 (3): 274-9o. Khan, Muhammad. 2018. I Am Thunder. London: Macmillan.

Khan, Muhammad. 2019. Kick the Moon. London: Macmillan.

Khan Phillips, Maha. 2012. "La Femme Pakistanaise Victime de l'Islam, un Discours qui se Vend Bien." Libération, September 13, 2012. http://www.liberation.fr/planete/2012/og/13/la-femme-pakistanaise-victime-de-l-islam-un-discours-qui-sevend-bien_846137.

Lewis, Philip. 1994. Islamic Britain:Religion, Politics and Identity Among British Muslims. London: I. B. Tauris.

Lewis, Philip. 2008. Young, British and Muslim. London: Continuum.

Lewis, Philip and Sadek Hamid. 2018. British Muslims: New Directions in Islamic Thought, Creativity and Activism. Edinburgh: Edinburgh University Press.

Malak, Amin. 2005. Muslim Narratives and the Discourse of English. Albany, NY: State University of New York Press.

Meetoo, Veena and Heidi Mirza. 2007. "There Is Nothing 'Honourable' About Honour Killings: Gender, Violence and the Limits Multiculturalism.” Women's Studies International Forum 30 (3): 187-200.

Mernissi, Fatima. 1991. Women and Islam: An Historical and Theological Enquiry. Oxford: Basil Blackwell.

Modood, Tariq. 2005. Multicultural Politics: Racism, Ethnicity and Muslims in Britain. Edinburgh: Edinburgh University Press.

Mohammad, Robina. 2015. "Transnational Shift: Marriage, Home and Belonging for British Pakistani Muslim Women." Social and Cultural Geography 16 (6): 593-614.

Mohanty, Chandra Talpade. 1984. "Under Western Eyes: Feminist Scholarship and Colonial Discourses." boundary 2 12/13: 333-58.

Mondal, Anshuman A. 2008. Young British Muslim Voices. Oxford: Greenwood.

Mufti, Aamir R. 2004. "Towards a Lyric History of India." boundary 2 (31.2): 245-74.

Patton, Chloe. 2018. "Racialising Domestic Violence: Islamophobia and the Australian Forced Marriage Debate." Race \& Class 6o (2): 21-39.

Phillips, Richard, Claire Chambers, Nafhesa Ali, Peter Hopkins and Raksha Pande. 2019. "Mobilizing Pakistani Heritage, Approaching Marriage." Ethnic and Racial Studies, https://doi.org/10.1080/01419870.2019.1674348.

Ranasinha, Ruvani. 2007. South Asian Writers in Twentieth-Century Britain: Culture in Translation. Oxford: Oxford University Press.

Ratti, Manav. 2013. The Postsecular Imagination: Postcolonialism, Religion, and Literature. New York: Routledge. 
Razack, Sherene H. 2004. "Imperilled Muslim Women, Dangerous Muslim Men and Civilised Europeans: Legal Social Responses to Forced Marriage." Feminist Legal Studies 12: 129-74.

Rozario, Santi. 2012. "Islamic Marriage: A Haven in an Uncertain World." Culture and Religion 13 (2): 159-175.

Shamsie, Muneeza. 2017. Hybrid Tapestries: The Development of Pakistani Literature in English. Karachi: Oxford University Press.

Shaw, Alison. 2006. "The Arranged Transnational Cousin Marriages of British Pakistanis: Critique, Dissent and Cultural Continuity." Contemporary South Asia 15 (2): 209-2o.

Steenkamp, Lize-Maree. 2019. Place, Space and Patriarchal Femininities in Selected Contemporary Novels by African Women Writers. Cape Town: University of the Western Cape PhD Thesis.

Westall, Claire. 2016. "Cricket and the World-System, or Continuity, 'Riskless Risk' and Cyclicality in Joseph O'Neill's Netherland." Journal of Postcolonial Writing $5^{2}(3): 287-3$ oo.

Yuval-Davis, Nira. 2011. The Politics of Belonging: Intersectional Contestations. London: SAGE. 